\title{
MRI and CT tracking of mesenchymal stem cells with novel perfluorinated alginate microcapsules Yingli Fu*1, Yibin Xie ${ }^{1}$, Dorota A Kedziorek ${ }^{1}$, Steven M Shea ${ }^{1}$, Ronald Ouwerkerk2 ${ }^{2}$, Tina Ehtiati ${ }^{3}$, Gary Huang1, Robert Krieg ${ }^{4}$, Frank Wacker ${ }^{1}$, Jeff WM Bulte ${ }^{1}$ and Dara L Kraitchman ${ }^{1}$
}

Address: ${ }^{1}$ Johns Hopkins University, Baltimore, MD, USA, ${ }^{2}$ National Institutes of Health, Bethesda, MD, USA, ${ }^{3}$ Siemens Corporate Research Inc., Baltimore, MD, USA and ${ }^{4}$ Siemens AG Healthcare Sector, Erlangen, Germany

* Corresponding author

from I3th Annual SCMR Scientific Sessions

Phoenix, AZ, USA. $21-24$ January 2010

Published: 21 January 2010

Journal of Cardiovascular Magnetic Resonance 2010, I2(Suppl I):OI4 doi:I0.1 I86/I532-429X-I2-SI-OI4

This abstract is available from: http://jcmr-online.com/content/I2/SI/OI 4

(C) 2010 Fu et al; licensee BioMed Central Ltd.

\section{Background and objectives}

Stem cell therapies, although promising for treating ischemic arterial diseases, suffer from poor engraftment and the inability to noninvasively monitor and track transplanted cells in vivo. Stem cell microencapsulation in conjunction with an imaging contrast agent provides a means to prevent cell immunorejection and enable cell tracking with appropriate imaging modalities. The objective of this study was to design and evaluate a novel MRIand CT-visible, immunoprotectable alginate microcapsule containing an imaging contrast agent, perfluorooctylbromide (PFOB), for mesenchymal stem cell (MSC) delivery.

\section{Methods}

Microencapsulation of bone marrow-derived rabbit $\mathrm{MSCz}$ $\left(1.5 \times 10^{6} \mathrm{cells} / \mathrm{ml}\right)$ was performed using a modified cell microencapsulation method with the addition of PFOB. MSCs viability was determined using a fluorometric assay. In vitro phantom studies using ${ }^{19} \mathrm{~F}$ MRI and c-arm CT imaging were performed to determine the minimum detectable number of PFOB Caps using standard clinical imaging systems. New Zealand White (NZW) rabbits ( $\mathrm{n}=$ 16) were randomized to receive 6 injections ( 500 capsules/injection) of unlabeled microcapsules, PFOB Caps, or naked MSCs in the medial thigh. X-ray angiograms, carm CT, and ${ }^{19} \mathrm{~F}$ MR images were taken within 1-14 days after injection in a rabbit PAD model. Intensity-weighted centroids of each injection site from CT images and postmortem 3D rendering volumes were determined after coregistration using 3D registration software (Dextroscope). Registration error was quantified by linear distance between paired CT and postmortem injection sites.

\section{Results}

The viability of rabbit MSCs encapsulated with PFOB was $90 \pm 3 \%$ immediately after encapsulation and remained high ( $88 \pm 5 \%$ at 4 weeks post-encapsulation). As few as 2 and 5 PFOB microcapsules could be detected in phantoms using c-arm CT and ${ }^{19} \mathrm{~F}$ MRI, respectively. In vivo visualization of PFOB microcapsules with c-arm CT images was confirmed in $95 \%$ of the injections whereas unlabeled capsules could not be detected (Fig 1A). PFOB microcapsule injections remained detectable by MRI and CT up to 2 weeks post-injection. Using ${ }^{19} \mathrm{~F}$ MRI, transplanted PFOB microcapsules in rabbit medial thigh were demonstrated $100 \%$ correspondence to the injection location on c-arm CT (Fig 1A, B). In the coregistered volumes, the mean offset between centers of mass at each injection site was 2.83 $\pm 0.85 \mathrm{~mm}$ (Fig 1C).

\section{Conclusion}

PFOB microcapsules provide an ideal microenvironment for maintaining MSC viability in vitro, while enabling the monitoring of MSC delivery and tracking of engraftment in vivo using clinical MRI and CT imaging systems. 

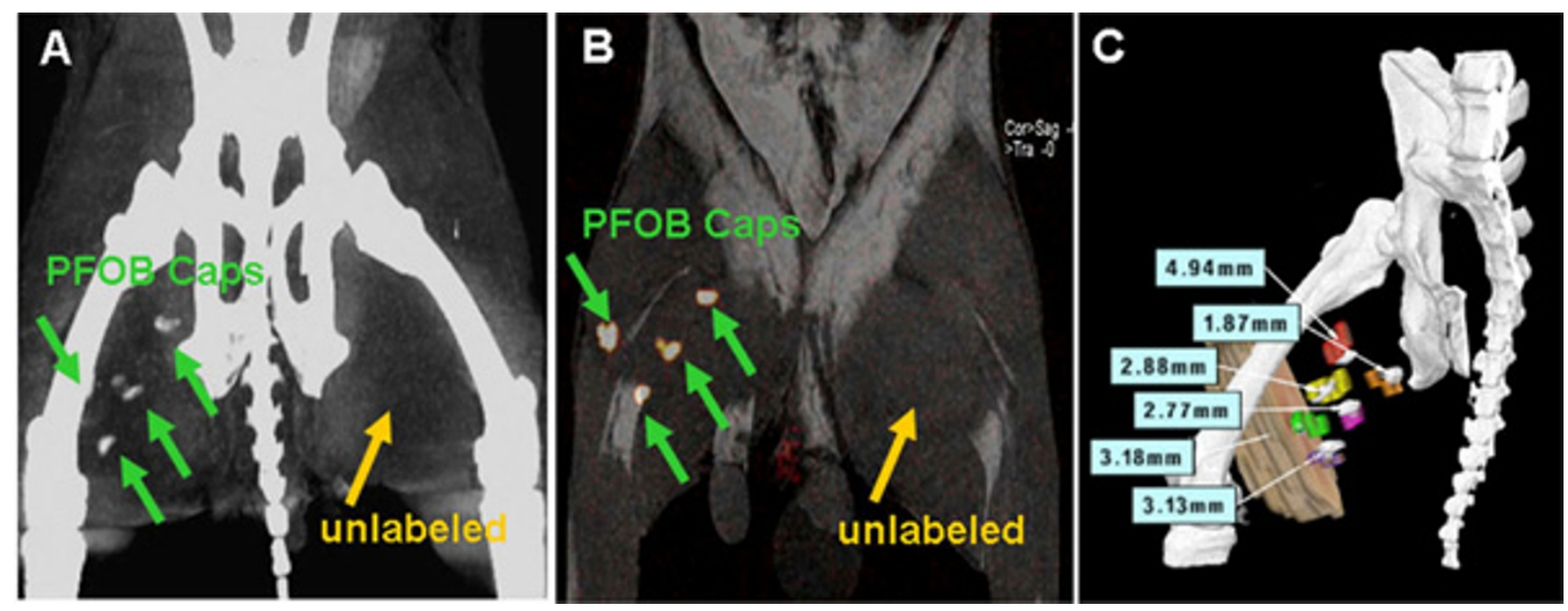

\section{Figure I}

(A) A c-arm CT angiogram demonstrating the detection of 4 PFOB injection sites in a rabbit medial thigh, while unlabeled capsules in the left thigh no detectable. (B) I9F MRI of the same rabbit showing one-to-one correspondence to the injection location on C-ARM CT. (C) Co-registering of threshold c-arm CT image of a rabbit with 6 PFOB Caps injection sites (gray) and postmortem 3D rendering volume of each injection sites (color) demonstrating the location of opacities on c-arm CR image is representative of PFOB Caps injections. Registration error for each injection site from a representative rabbit is shown.

Publish with Bio Med Central and every scientist can read your work free of charge

"BioMed Central will be the most significant development for disseminating the results of biomedical research in our lifetime. "

Sir Paul Nurse, Cancer Research UK

Your research papers will be:

- available free of charge to the entire biomedical community

- peer reviewed and published immediately upon acceptance

- cited in PubMed and archived on PubMed Central

- yours - you keep the copyright 